\title{
Lysophospholipid Acyltransferase 2
}

National Cancer Institute

\section{Source}

National Cancer Institute. Lysophospholipid Acyltransferase 2. NCI Thesaurus. Code C114573.

Lysophospholipid acyltransferase $2(520 \mathrm{aa}, \sim 60 \mathrm{kDa})$ is encoded by the human MBOAT2 gene. This protein is involved in lysophospholipid metabolism. 